\title{
Dynamic grating recording in lyotropic ionic smectics of metal alkanoates doped with electrochromic impurities
}

\author{
A.B. Bordyuh ${ }^{a}$, Yu.A. Garbovskiy ${ }^{\text {b }}$, S.A. Bugaychuk ${ }^{b}$, G.V. Klimusheva ${ }^{b, *}$, T.A. Mirnaya ${ }^{c}$, \\ G.G. Yaremchuk ${ }^{\mathrm{c}}$, A.P. Polishchuk ${ }^{\mathrm{a}}$ \\ ${ }^{a}$ National Aviation University, Prospect Komarova 1, 03058 Kyiv, Ukraine \\ ${ }^{\mathrm{b}}$ Institute of Physics, Prospect Nauki 46, 03680 Kyiv, Ukraine \\ ${ }^{\mathrm{C}}$ Institute of General and Inorganic Chemistry, Prospect Palladina, 32/34, 03142 Kyiv, Ukraine
}

\section{A R T I C L E I N F O}

\section{Article history:}

Received 4 June 2008

Received in revised form 15 October 2008

Accepted 30 November 2008

Available online 20 January 2009

\section{PACS:}

42.70.Df

42.70.Gi

42.70.Ln

Keywords:

Viologen

Lyotropic ionic smectic

Dynamic holography

Photoconversion

\begin{abstract}
A B S T R A C T
In this work, we investigated nonlinear-optical properties in lyotropic ionic liquid crystals (LILC) of potassium caprilate doped with electrochromic impurities (viologens). It is known that after applying a direct electric field to the LILC-viologen cells colouration of samples is observed [1]. Dynamic grating recording under the action of nanosecond pulse laser radiation was obtained for the coloured samples. We analyzed the origin of the optical nonlinearity in the investigated materials taking into account their electrochemical and electrooptical properties. To explain grating recording in LILC doped with viologens, we proposed the mechanism of photoconversion in viologen molecules.
\end{abstract}

(c) 2008 Elsevier B.V. All rights reserved.

\section{Introduction}

Bipyridyl quaternary salts (viologens) in solutions [2,3], polymeric matrixes [4], liquid crystals [5] and also in crystalline state [6] exhibit different physical and chemical properties such as electro-, thermo- and photochromism. Systems based on viologens could be used as redox indicators, light-sensitive systems, electron transfer catalysts, colour filters of variable density, etc. [7]. In this work we investigated the dynamic holographic recording in lyotropic liquid crystals of metal alkanoates with various electrochromic impurities under the action of pulse nanosecond laser radiation. For the first time, mechanisms of the optical nonlinearity in LILCviologen samples were proposed and considered. Our researches show that LILC of metal alkanoates doped with viologens are perspective materials for using in multifunctional photonic elements and fast optical devices.

\footnotetext{
* Corresponding author. Tel.: +38 044 5257841; fax: +38 0445251589.

E-mail address: klimush@iop.kiev.ua (G.V. Klimusheva).
}

\section{Materials and methods}

The potassium caprylate mixed with water in 1:1 proportion to form a lyotropic ionic liquid crystal was used as a matrix (the chemical formula is $\mathrm{C}_{7} \mathrm{H}_{15} \mathrm{COOK}: \mathrm{H}_{2} \mathrm{O}$ ). Electrochromic impurities of viologens were dissolved in the LILC matrix (2 wt.\%). LILC have greater viscosity as compared to liquid solvents, which leads to increasing the lifetime of coloured viologen derivatives. Two different viologens were used, namely: (1) N, $\mathrm{N}^{\prime}$-diheptyl-4,4'-bipyridilium dibromide $\left(\mathrm{HB}^{2+} 2 \mathrm{Br}^{-}\right)$and (2) $\mathrm{N}^{\prime} \mathrm{N}^{\prime}-\mathrm{di}(2$-carboxyethil)-4,4'bipyridilium dichloride $\left(\mathrm{CEB}^{2+} 2 \mathrm{Cl}^{-}\right)$. The common structural formula of both viologens is as follows:

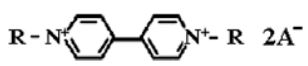

where $\mathbf{R}$ is a substitute, $\mathbf{A}$ is a counterion. In the case of $\mathrm{HB}^{2+} 2 \mathrm{Br}^{-}$ $\mathbf{R}=\mathrm{C}_{7} \mathrm{H}_{15}, \mathbf{A}^{-}=\mathrm{Br}^{-}$and $\mathbf{R}=\left(\mathrm{CH}_{2}\right)_{2} \mathrm{COOH}, \mathbf{A}^{-}=\mathrm{Cl}^{-}$for $\mathrm{CEB}^{2+} 2 \mathrm{Cl}^{-}$.

The structure of both pure and doped LILC were investigated earlier using the small angle X-ray scattering technique [8]. LILC based on potassium caprylate have the smectic A phase. It was 